\title{
HISTORICAL ROOTS OF SEMANTICS AND RESEARCH IN THE MODERN ASPECT
}

\author{
Mukhammad Khodjakhonovich Khakimov
}

Doctor Of Philological Sciences, Professor, Fergana State University, Uzbekistan

Khavaskhon Nurmamatovna Shokirova

Candidate of Philological Sciences, Associate Professor of The Regional Center For Retraining And Advanced Training Of

Public Education Of Fergana Region, Uzbekistan, Fergana City

\section{ABSTRACT}

This article discusses semantics, one of the most important components of linguistics, and the history of its origins, its research, and research issues.

KEYWORDS: - The meaning, the motion, semiotics, semantics, syntactic, pragmatics, a language, a speech, a sign, designatum, interpreter, an object, a subject, an addressee.

\section{INTRODUCTION}

Semantics, as described by the scientist Ch. Morris, is the relation of the sign to the object it represents, and calls the object of this expression through the concepts of designat and denotation. Designat is a class of objects represented by a character, and denotation is a member of this class. The German philosopher Georg Klaus advocated distinguishing between the performance of two different functions within the relation of a sign to an object, namely the expression of meaning or content and the expression (naming). All semiotics acknowledge that semiosis consists of three parts, and that these parts are interrelated, and describe them in a single semiotic framework (triangle or rectangle). The interrelationship between the parts is reflected in the content of each character, that is, all the characters at the same time in semantic, syntactic and pragmatic form - in the text, in the speech environment, express meaning, content. If we look at a number of textbooks and manuals on this, we come across different opinions. Academician Stepanov in his work "Semiotics" is based on the ideas of Ch.U.Pierce and Ch.Morris and divides the character into 3 parts. [1]. M.A.Krongaus and I.M. Kobozeva also support the study of semiotics in three parts, following this tradition. [2].

In nineteenth-century linguistics, the greatest focus was on research in phonetics and morphology. Diachronic semantics, with its first principles, required the study of changes in word perception and the appearance of rhetoric, especially the social aspect of tropes. [3] 
CURRENT RESEARCH JOURNAL OF PHILOLOGICAL SCIENCES 2(6): 93-97,

May 2021 DOI: https://doi.org/10.37547/philological-crjps-02-06-19

ISSN 2767-3758

(C)2021 Master Journals

\section{Crossref do) 8 Google}

Accepted25thJune, 2021 \& Published 30thJune, 2021

In the early twentieth century, semantics rejected research in the diachronic direction and set itself the task of analyzing the synchronous representation of concepts in its favor. Starting with I.Thir's research, which was based on semantic and onomasiological approaches, these studies became known as lexicology. Lexical semantics is such a basic unit of study that in an image that brings it closer to the Sepir-Uorfa hypothesis, the whole world recognizes lexical categories at the core of a particular language. The approach to lexical semantics introduced to it a prohibitive content and a special individuality. This was evident in the publications of the 1990s, in particular in English, German and French, and in textbooks and manuals in Russian[4,9].

Semantics - greek. semantikoc- meaning, expressive, expressive:

1) The whole content, meaning, information, expressed through language or any of its units (word, grammatical form of the word, phraseology, phrase, sentence);

2) Expresses the concepts of lexical elements.

Consequently, the object of study of semantics is basically a complete, independent system of meanings of words and phrases. suggests the term and uses it in his letters as well.14 years later his famous book "Essai de semantique. Science des significations "[Breal 1897]. In the 1960s, these two terms, semantics and semantics, were further defined and strengthened. $\mathrm{H}$. Kronasser mentions that the term semasiology was mentioned earlier in 1826. [Kronasser 1952, 29 prim.] [4, 6].

Research on semantics [Apresyan 1995, Arutyunova 1976, Gorodetskiy 1969, Novikov 1982, Paducheva 1985, Stepanov 1985, Shmelev 1977, .S.Akhmanova, N.G.Komleva, Yu.V.Rozhdestvensky and L.I.Skvortsova et al.], modern textbooks on semantics, mainly those published in the 70s and 80s, have not been replaced by their predecessors.

M.V. Nikitin's (1996) textbook was mainly intended for the study of lexical semantics and its historical aspect. It should be noted that a number of books in Russian explore the logicalphilosophical-semantic feature, for example, the study of Tondl in 1975. [Translated from the Czech language: Pavilenis 1983]. In 2000, I. M. Kobozeva's book Linguistic Semantics has become a new generation textbook. This textbook is distinguished by the fact that it expresses the views of the Moscow Semantic School. Beginning with a short essay on the history of semantics, this 3-chapter textbook covers all aspects of lexical semantics: concept of concepts, types, lexical and grammatical concepts, signification and denotative components, lexeme denotation, pragmatic component, the speaker's attitude to the addressee, semantic field correlation, synonymy, hyponymy, conversion, associative attitude, monosemia, polysemy, phenomenon, homonymy. Chapter III analyzes important issues such as the semantics of pragmatic components, the representative component of communication, the metatyl dictionary, the syntax (grammar) part of metatyl, the actual division of speech, the central and peripheral part of metatyl in semantic form. The textbook shows that semantics, as a branch of language that studies the general laws of language, covers its main problems from morphemes to the full text.

Studies that have been variously named until this period, such as the 1951 English translation of S.C. Ullmann's The Principles of Semantics and

H. Kronasser's Handbuch der Semasiologie in German in 1952, Lovel Bouman's 1973 book The Semantics of the Modal Auxiliaries in Contemporary German, and Jennifer Soates's 1983 book The Semantics of the Semantics. modal auxiliaries ", Lukach, W. Ellyn's" Semantic 
CURRENT RESEARCH JOURNAL OF PHILOLOGICAL SCIENCES 2(6): 93-97,

May 2021 DOI: https://doi.org/10.37547/philological-crjps-02-06-19

ISSN 2767-3758

(C)2021 Master Journals

\section{Crossref do) 8 Google}

Accepted25thJune, 2021 \& Published 30thJune, 2021

and pragmatic language disorders "published in 1980, in 1978 by Susan S., a scientist at the University of Chicago. Bean's book, Symbolic and Pragmatic Semantics, saw the light of day. V.A. Zvegintseva's "Semasiology" also contributed to the development of the field. Only in the 1960s did the term "semantics" take on an independent and central place. [Krongauz M.A. That work.S6]. An English linguist who worked more productively in semantics, $\mathrm{Dj}$. Lions are. Suffice it to mention the popular 2-volume collections, published in 1977 and a little later - in 1981 and 1995. [Lyons 1977, 1981, 199-51]. These books and other works by Lyonz contain a collection of information on language, linguistics, as well as linguists and semantics. - Layonz 2003.]

Dj. Lyons's manuals were primarily for student linguists. "Linguists who have raised the problem of semantics among the authors of many textbooks and textbooks on semantics - Palmer 1981; Hurford, Heasley 1983; Allan 1986; Frawley 1992; We see that Hofmann 1993 and Saeed (1997) are also listed. This textbook, which has caused great problems in different languages, is of no value and worth remembering, says Krongauz, on the contrary. Greymas, Dj. Katts and Dj. Lich [Greimas 1966; Katz 1972; Leech 1974] should be noted. Each has taken semantics to a new level. "[Krongaus M.A. Same work.] In recent years, there has been a proliferation of research on data sets, or semantics itself, or on semantic problems. These include the HSK series (Handbiicher zur Sprachund Kommunikationswissen-schaft) in 1991, the nearly 1,000-page reference book (Semantics directory) published in 1995, and the Handbook of pragmatics. In addition, a new three-volume edition, the Encyclo-pedic dictionary of semiotics, was published in 1994. In 1997-2004, a 4-volume reference book "Semiotics" was published in the HSK seriesIn addition to a large number of general linguistic dictionaries, a onevolume encyclopedic dictionary Ducrot, Todorov, published in 1972, as well as a two-volume edition describing the structure and performance of linguistics in the 1970s, Greimas, Courtes (1979) (2nd edition in 1986) are cited. was further supplemented and included discussion questions and discussions). Textbooks and reference books in English, German, and French, especially in Russian, were active in the 1990s. There were books on semantics in Russian linguistics (Arutyunova 1976, Gorodetsky 1969, Novikov 1982, Paducheva 1985, Stepanov 1985, Shmelev 1977, Apresyan 1995, etc.), which are distinguished by their high value. A textbook on semantics was, of course, needed in the 1960s and 1970s, and then in the 1980s and 1990s. Today, it can be said that Russian semantics is evolving. The achievements of the Moscow Semantic School, which works with logical analysis, go far beyond the West. But now, with the proliferation of some gaps and the elimination of these arguments (not to mention a slight backwardness, Russian semantics is developing considerably), there were painful points between Russian and Western science, especially in education. The sudden interruption seemed to suggest that in response to the Handbook of Pragmatics, Russian linguistics was content with an article entitled Marxist Linguistics.

Today's textbook on semantics should elevate Russian semantics to a higher level (arguably, the Moscow Semantic School approached the laws of functional grammar and other Russian semantic schools in the field of logical analysis) to study new and as yet undefined Western linguistics. The task was not only to learn, but also to unite in addition to the change and development of science. It is important to note that the incompleteness of the published reference books (in particular, even in global, structural and compositional studies) further clarified these aspects. Such inaccuracies made the semantics a bit more complicated, making it more difficult 
CURRENT RESEARCH JOURNAL OF PHILOLOGICAL SCIENCES 2(6): 93-97,

May 2021 DOI: https://doi.org/10.37547/philological-crjps-02-06-19

ISSN 2767-3758

(C)2021 Master Journals

\section{Crossref do) 8 Google}

Accepted25thJune, 2021 \& Published 30thJune, 2021

and inconvenient. This led to a lack of quality in semantics. That is why the textbooks and manuals should be supplemented with new information and ideas, which will determine its structure, - said Krongauz in his textbook[4, 9].

This textbook begins by highlighting the place, connection, and relationship of semantics to other disciplines. The relationship of semiotics with philosophy, logic, general semantics is defined.1 Chapter 1 is called Semiotics and is studied in 3 parts. In Chapter 2, basic concepts and problems, metatyl, language function, concept, semantic methods, Humboldt's views and opposites, Sepir-Worf's hypothesis, in the following chapters, the concept of word, language units, semantic laws and models of language, from essence to sign, generative semantics, issues of cognitive linguistics, speech act theory, pragmatics are considered. The author studies communicative implication in 3 . Grays 'hypotheses, the speaker's attitude problems are analyzed.

In 1995, a large part of the manual of the scientist Yu.D. Apresyan was executed on the basis of a common plan and concept and published under the title "Lexical semantics". His keywords are:

1) the principle of language integration, in the form in which all the features of the word retain their power, the rule for relevant, the laws of the different forms of the word are reflected;

2) the principle of lexicography, which requires that each word have its own autonomous, that is, separate and uniquely colorful world, with all its richness;

3) the elevation of the lexical system to higher levels and the interference of the ideas of lexicography associated with it, the consistent features, constitute the linguistic laws;
4) provides for the establishment, reconstruction, formation of a simple secular form of lexical and grammatical materials [5].

Such well-known linguists in the linguistics of the twentieth century, both individually and as a whole, at the level of semantics and lexicography, which are characteristic and contradictory, are L. V. Shcherba, Sh. Balli, E. Sepir, K. Erdman, Dj. Firt, V. V. The Vinogradovs did the research. Modern semantics has formed the following scientific principles:

a) Being is a word sign, it is not scientific, it is a concept of a natural thing, in another case it is an association of emotion (valeur emotive, Gefiihiswert, feeling, tone) , 1940, Firt 1935, 1951];

b) The verbal motivation of this being, the fulfillment of a separate "intellectual language-identifier" [Balli 1921, 1926], is a direct involvement of semantics in a clear and vivid language [Sepir 1944];

c) Words in a language communicate freely with each other, i.e. not only on the basis of the notion of information; the free connection of words in a language with each other, not only the word and the information about it, but also its meaning is formed as a relation; the process of word combinations and speech devices is subject to separately limited lexical and constructive phenomena; in the process of joining, the phrase and the sentence are divided into separate basic lexical and constructive. [Balli 1926, Vinogradov 1947a, 1947b, 1953];

d) Even the content of free phrases; evaluates the concepts of complex products with the dual content-essence of the more interesting laws that exist.

e) Even the content of free phrases and the words in whole phrases are not always the same; evaluates not only the ambiguous 
CURRENT RESEARCH JOURNAL OF PHILOLOGICAL SCIENCES 2(6): 93-97,

May 2021 DOI: https://doi.org/10.37547/philological-crjps-02-06-19

ISSN 2767-3758

(C)2021 Master Journals

Crossref dof 81 Google

Accepted25thJune, 2021 \& Published 30thJune, 2021

content of the more interesting laws that exist, but also the concepts of complex products.

Semantics as a science began to develop in the second half of the 19th century and has gone through several qualitatively different stages. Some of the most important work of semantics has been done by philosophers, not philosophers, since the late nineteenth century. Over the last 50 years, approaches to semantics have multiplied and become one of the brightest areas of linguistics, "Trask said. Semantics is the attempt to explain the knowledge of any speaker who knows the language, allowing the speaker to convey the truths, intentions, and products of the imagination to another speaker. A long-standing problem in semantics is the comparison of its subject matter, some of which correspond to the usual understanding of language and computational semantics.

\section{REFERENCES}

1. Stepanov Yu. Semiotika. M. 1983. p.43

2. Axmanova O.S. Dictionary of linguistic terms. -M .: Sovetskaya encyclopedia, 1969. p.608.

3. M.A. Krongauz "Semantics". 2005. p.19

4. Susov I.P. "Linguistic pragmatics". East-West2006, p.20.

5. Krongauz M.A. Semantics. M:. Academy. 2005. p.9

6. Yu.D. Apresyan "Lexical semantics". 1995. p. 3

7. Iskandarova Sh. Study of vocabulary as a semantic field. -Tashkent, Fan, 1998.

8. 7.Kobozeva I.M. "Linguistic semantics" .- M .: 2000. p.352.

9. Kronasser H.Handbuch der semasiologie.1952, p.204.
10. Lyons

J.Semantics.Cambridge University.1977. p.24.

11. Safarov Sh. Semantics. $T$,: State Scientific Publishing House of the National Encyclopedia of Uzbekistan.2013. p.344.

12. Stepanov Yu.S.Semiotics. -M .: 1983. p.634. 